\title{
The Logic of Consumer Credit Reform**
}

\author{
George J. Wallace
}

A consumer credit reform movement has been mobilizing to restrict or abolish remedies such as the cognovit note, balloon clause, deficiency judgment, wage garnishment, holder in due course status, and repossession without hearing. Momentum has been added by recent judicial decisions such as Fuentes $v$. Shevin, ${ }^{1}$ in which replevin without notice in most circumstances was declared unconstitutional. But some commentators ${ }^{2}$ have objected that the ultimate effect of such reform may be to limit the amount of credit available to low-income consumers. Critics contend that limiting the creditor's ability to coerce repayment will increase creditor cost, thereby increasing the price or reducing the volume of credit available, with the most severe effects falling on lowincome borrowers. Three assumptions underlie much of the past criticism of consumer credit reform: First, that restrictions on creditor remedies, such as those noted above, will increase the price or reduce the volume of credit; second, that such tampering with consumer sovereignty will result in allocative inefficiency in the credit market; and third, that this increase in price or reduction in volume of credit will disproportionately affect low-income consumers and thus offend our sense of distributive justice. This article will question the accuracy of the first assumption, and suggest that gains in allocative efficiency and

* I would like to thank Professor Richard Speidel of the University of Virginia, Professors D. Daniel Ellis, James Meeks, Benjamin Hopkins, and Mark Schantz, of the University of Iowa, for helpful comments on earlier drafts of this paper. Mfarc Harding of the University of Iowa provided able research help. Of course, I remain totally responsible for the contents of the paper. Since D. Stanler, MI. Girti, B.ankiurtcr: Proules, PROCESS, AND REFORM (1971) was not available when the notes for this article vere prepared, no attempt was made to incorporate its findings.

$t$ Associate Professor of Law, University of Iowa College of Law. B.A. 1964. Yale University; LL.B. 1967, University of Virginia Law School.

1. 407 U.S. 67 (1972). Other recent cases and proposed statutes have both direculy and indirectly approached the position that a hearing must be had prior to repossession. National CoNsumer Law Center, National CoNsugrer ACT (First Final Draft) (1970) SS 5.204, 5.208, for example, requires such a hearing. See Adams v. Egley, 338 F. Supp. 614 (S.D. Cal. 1972). Cf. Sniadach v. Family Finance Corp., 395 U.S. 337 (1969). See also Blair v. Pitchess, 5 Cal. 3d 258, 486 P.2d I242, 96 Cal. Rptr. 42 (1971); Iaprease v. Raymours Furniture Co., 315 F. Supp. 716 (N.D.N.Y. 1970).

2. See Kripke, Consumer Credit Regulation: A Creditor-Oriented Viewpoint, 68 Cotun. L. REv. 445 (1968) [hereinafter cited as Kripke, Credit Oriented]; Kripkc, Gesture and Reality in Consumer Credit Reform, 44 N.Y.U. L. REv. I (1969) [hereinafter cited as Kripke, Gesture]. Professor Kripke was not the first to make this argument, but he made it with the greatest force and lucidity. See, e.g., Curran, Legislative Controls as a Response to Consumer-Credit Problems, 8 B.C. IND. \& CoM. L. REv. 409, 432 (1967). Not all of Professor Kripke's articles, or those of others, take the same position on the same point, compare Kripke, Credit Oriented, at 485 with Kripke, Geslure, at 33 p.142. For this reason, I have chosen to discuss a summary version of such criticism. 
increases in distributive justice may result even if reform increases the price or reduces the volume of credit. ${ }^{3}$

\section{Consumer Credit Reform and the Price and Volume of Credit}

The assumption that consumer credit reform will increase the price or reduce the volume of credit rests upon two minor premises: First, that significant reform will be costly to the creditor; and second, that he will respond by either raising the price or reducing the volume of credit offered. While there is some empirical evidence supporting these premises, there is also some to the contrary, and their validity is at best uncertain.

\section{A. The Probability that Reform will be Costly to the Creditor}

Significant reform need not increase creditor costs. Additional costs will result only if reform leads to a higher rate of default, greater quantities of uncollectible debts, or more costly collection procedures.

\section{Will reform increase the rate of default?}

Those who contend that a significant reduction in coercive creditor remedies will increase the rate of default find in the present legal system elements of moral suasion, deterrence, and coercion which prompt the debtor to meet his obligations. They appear to reason that if creditor remedies are restricted, the legal system will no longer support the principle that debts must be repaid, deter default through fear, or coerce repayment through direct sanctions. As a result, the rate of default will increase. ${ }^{4}$

3. Traces of the approach taken by this paper can be found in a number of articles, although none seem to have fully acknowledged the nature of the reform decision nor

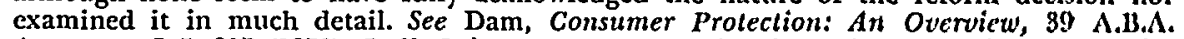
ANmTrusr L.J. 917 (1970); Leff, Injury, Ignorance and Spite: The Dynamics of Coercive Collection, 80 YALE L.J. I (1970) [hereinafter cited as Leff, Spite]; Slawson, Standard Form Contracts and Democratic Control of Lawmaking Power, 84 HARv, L. REv. 529 (1971); Resort to the Legal Process in Collecting Debts from High Risk Credit Buyers in Los Angeles-Alternative Methods for Allocating Present Costs, 14 U.C.L.A. L. REv. 879 (1967) [hereinafter cited as U.C.L.A. Project]. See also Buchanan, In Defense of Caveat Emptor, 38 U. CHI. L. Rev. 64 (1970).

An analogy to accident costs underlies the use I have made of Professor Calabresi's book in developing this analysis. While I will not frequently cite him hereafter, $I$ owe him a great debt. See G. Calabresi, The Costs of Accidents (1970).

4. Professor Andenaes speaks of the "moral influence of the criminal law" and the "moral or socio-pedagogical influence" when he describes an analogous effect on crimlnal behavior. See Andenaes, The General Preventive Effects of Punishment, 114 U. PA. L. REv. 949 (1966) [hereinafter cited as General Preventive]. The parallel concept in Andenaes' writings is "mere deterrence." See id. at 950 . It would be problematic to analogize 
Yet it seems just as reasonable to assume that the debtor's own morality and sense of obligation, and those of his community, are equally determinative of whether or not he repays. ${ }^{5}$ There appears to be a clear consensus among almost all segments of society regardless of the efficacy of official sanctions, that obligations must be fulfilled. ${ }^{\circ}$ Professor Caplovitz found a strong willingness among debtors to meet their obligations, even in the face of adversity, despite an absence of effective legal sanctions against nonpayment. ${ }^{7}$ The moral and deterrent impact of creditor remedies may depend less on their severity than on their efficacy in reinforcing ethical motivation and social disapproval, and their certainty of enforcement. ${ }^{8}$ For example, there is evidence that debtors find the mere service of process to be a powerful impetus to repayment. ${ }^{9}$

Finally, it seems likely that significant non-legal sanctions would operate through credit-rating systems even in the absence of legal coercion. A restriction of creditor remedies should encourage the development of more accurate credit bureaus, providing information that should permit the identification of high-risk debtors, particularly those with a history of delinquency. In this way, if legal regulation subsides, informal regulation through the market should continue to provide a substantial deterrent to defaults. ${ }^{10}$ Thus, without empirical support it

the deterrent impact of criminal law sanctions to the credit system, because it is not known how closely defaulting debtor behavior resembles criminal behavior.

Any attempt to analogize between credit and criminal behavior must takc into con. sideration a number of interrelated factors. One is the degree of rationality involsed: Obtaining credit is probably a fairly irrational and impulsive process during which the debtor's concentration is on what he will do with the money rather than the need to repay. Since the rationality of the conduct is by no means clear, the writings on "ceonomic" crimes would not seem particularly relevant. Moreover, the wrongful act itself is not particularly severe in contrast with major crimes against person and property. Thus, the ethics involved and the strength of ethical controls may be quite different. Nevertheless, socialization may act quite strongly to encourage fulfillment of obligations. Finally, the certainty of apprehension and enforcement is probably greater with credit default than with almost all crimes.

5. For the suggestion that milder punishment will more effectively teach conduct consistent with established norms, see Turner \& Wright, Effects of Secerity of Threal and Perceived Availability on the Attractiveness of Objects, 2 J. PERSONALITI aNd SOclal PSYCHOLOGY 128 (1965).

6. See, e.g., H. Jacob, Debtors in Court 71, 110 (1969).

7. See D. CAPIOvit,, DeBtors in Default 5-70, 5-71 (mimeographed prepublication ed. $1970,1971)$. See also, H. JACOB, supra note 6, at 71 .

8. It has been suggested, for example, that sanctions milder than used at present against bad driving, when enforced by a point system, may have greater psychological effect on poor driver behavior than harsh penalties. See Cramton. Driter Beliavior and Legal Sanctions: A Study of Deterrence, 67 Micit. L. REv. 421. 432-33 (1969). Most criminal experts argue that it is the certainty of enforcement rather than the secerity of the sanction which assures compliant behavior. See Andenaes, General Preventive, supra note 4. at 960-64.

9. See D. Caplovitz, supra note 7, at 11-35, 11-36.

10. Presumably creditors who had better information about the credit burden of their prospective customers could either refuse to give credit or could price discriminate 
is simply not clear that restrictions on coercive creditor remedies will dilute either the moral suasion or deterrent effect on defaultors.

\section{Will reform increase uncollectible defaulted debts?}

The contention that restriction of creditor coercion will necessarily increase the number of uncollectible debts is equally challengeable. A debt becomes uncollectible primarily due to the recalcitrance of the debtor and the encumbrance of his assets. Reducing coercive remedies may not, in fact, significantly alter either of these factors.

Legal coercion applied after default seems even less likely to reduce debtor recalcitrance than when it is applied before. First, the motivation to repay after default may be considerably lower, because the debtor has already endured whatever sense of shame or failure accompanies default. Moreover, debtors who have defaulted have usually done so because they are already under considerable financial pressure; repaying after default would mean even greater hardship.

A reformed system of consumer credit, however, might still arouse fear and psychological pressure sufficient to induce potential defaulters to continue repayment at the same or nearly the same rate as under more coercive remedies. Of particular importance is the fact that once they have defaulted, debtors still know that they will be "apprehended" and be under some further legal obligation.

It is doubtful, moreover, that creditors now gain very much from coercive remedies which allow them to reach debtors' assets directly. Coercive remedies may themselves encumber remaining assets and thus make repayment all the more difficult. This is particularly true where the debtor's major source of funds is future income. Coercive remedies tend to eliminate this asset when, for example, employers annoyed with having to garnish wages could respond by firing the debtor, or when garnished employees lose their incentive to continue working. Repossession or execution are also often inefficient remedies because the creditor rarely receives full repayment. Indeed, the expense of some coercive measures may even exceed their return. ${ }^{11}$ The only satisfaction

against riskier customers. Creditors who did price discriminate should be requircd to disclose to the debtor why a higher rate was charged so that the advantages of favorable debtor behavior might then be made clearer, and the deterrent effect increased.

11. It is possible, however, that legal collection does produce a significant amount of savings on defaulted debts even though it does not result in full collection. This is par. ticularly true in cases where the security given is easily resaleable and does not depreci. ate rapidly, e.g., automobiles. Any amount collected would seem worthwhile as long as it is larger than the cost required to collect it. Whether collection actually does produce such an amount in a significant number of cases is completely unknown. 
a creditor realizes in such situations, as Professor Leff has shown, ${ }^{12}$ is spite.

\section{Will reform mean more costly collection procedures?}

While restriction of creditor coercion might well cause short-term increases in collection costs, other consumer credit reforms, geared less to the elimination of harsh remedies and more toward positive creditor or debtor services, may actually produce savings which would more than offset these increases. More efficient information systems could reduce default rates by providing creditors with more complete data on potential borrowers; therapeutic counseling might reduce the number of debtors who repeatedly find themselves in credit difficulty, by advising potential borrowers and by helping defaulted debtors deal with their debts. While such reforms would obviously not be cost free, in the absence of clear empirical evidence, one cannot conclude that reforms of this type would inevitably have a noticeable effect on the price or availability of credit.

\section{B. The Probability that the Creditor will Respond to Increased Costs by Raising the Price or Reducing the Volume of Credit}

Any actual increase in costs to the creditor that does result from restricting coercion will produce price increases or volume reductions only if the creditor's cost structure forces such a response. Several studies suggest a direct relationship between the overall price of credit and the size of the creditor's provisions for bad debts. ${ }^{13}$ But such provisions

12. See Leff, Spite, supra note 3.

13. The literature is discussed in Shay, Factors Affecting Price, I"olume and Credit $R$ isk in the Consumer Finance Industry, $25 \mathrm{~J}$. Findsce 503 (1970). Regression analyses have demonstrated a strong correlation between the provision for bad debts and average loans outstanding. See also G. Gordon, J. Wheatzy, R. Gaedeke, H. Hall \& D. MaYiad, The Impact of a Consumer Credit Interest Limitation LAw (1970); Comment, An Empirical Study of the Arkansas Usury Law: "With Friends Lilke That . . ." I963 U. It.. L.F. 544 (1968).

The most sophisticated studies trying to relate terms on which credit is extended to default risk are limited to consideration of maturities and downpajments. Sec Furstenberg, Default Risk on FHA-Insured Home Mortgages as a Function of the Terms of Financing: $A$ Quantitative Analysis, 24 J. Finance 459 (1969).

The most that such studies suggest is that creditors' operating costs and the risk of the loans granted are directly correlated. But these studies pertain to the classes of risk which creditors will take on if they can charge certain prices. They are not relevant to predicting how the behavior of a class of debtors who can be served within the existing legal structure of rates will change if collection practices are restricted. The studies purport to demonstrate creditor behavior, not consumer bchavior.

Creditors may find that when they expend less money and effort collecting debts, their operating costs remain the same (or even decrease), because any increase in the cost of bad debts is compensated for by savings in collection costs. There is some indication 
may not be directly related to the cost of dealing with high-risk debtors. At least one study has found no significant relationship between the level of debtor risk and the price of the credit offered. ${ }^{14}$ Thus, provisions for bad debts may merely signal creditors' lack of efficiency or vigor in collecting, ${ }^{15}$ shaped in part by the fact that creditors often operate under imperfect competition and are rarely under strong pressure to keep their expenses as low as possible. Faced with increased collection or default costs and an elastic demand for credit, creditors may well respond by streamlining their presently inefficient collection efforts rather than by raising prices or curtailing loans; and, as has already been suggested, more efficient collection procedures need not mean harsher collection tactics.

None of this is meant to suggest that an increase in the price or a reduction in the volume of credit offered after the elimination of creditor coercion is impossible. It is only to note that they are not necessary and direct consequences, given the present state of empirical research. A thorough appraisal of any specific reform should consider the probabilities of such results but then move on to a second and perhaps more important question: What would be the impact of reform on the efficient use of all resources?

\section{Consumer Credit Reform and Allocative Efficiency}

One basis for evaluating consumer credit reform must be its effect on the allocative efficiency of the credit market. Allocative efficiency is achieved when the quantity of credit purchased maximizes social gains from credit resources relative to potential gains from all other resources. Thus, under perfect allocative efficiency, debtors would purchase credit up to and not beyond that point where the last dollar spent on credit produces more net benefits to society than if it were spent elsewhere. This perfectly allocated condition could obtain if all the social costs and benefits generated by a credit transaction were reflected in the credit contract and if all imperfections were eliminated from the

that when creditors use a particular remedy a great deal, the return for each use of the remedy declines quite drastically after a certain point. See, e.g., D. Curlovirz, supra note 7 , at $12-69$.

14. See Goudzwaard, Rate Ceilings, Loan Turndowns and Credit Opportunity, 6 W. Econ. J. 404 (1968); Goudzwaard, Consumer Credit Charges and Credit Availability, 35 S. ECON. J. 214 (1969).

15. See Goudzwaard, The Price-Volume Structure of the Consumer Credit Industry: A Discussion, 25 J. Finance 526 (1970). 
credit market. ${ }^{16}$ Although the fulfillment of these conditions may be difficult, ${ }^{17}$ entailing huge administrative costs, $^{18}$ the consumer credit market could be made more allocatively efficient than it now is, by taking measures to minimize market imperfections and bring as many credit-generated costs and benefits as possible to bear on the credit contract. Another way to make the credit market more allocatively efficient would be to impose direct controls after deciding on an optimal amount of credit by careful analysis of all relevant costs and benefits and then allocating credit accordingly.

Of course any tampering with the present credit market would involve probabilities and uncertainties. The risk that debtors, creditors, or the market will behave in unforeseen ways would have to be reflected in the decision to initiate a specific reform. Moreover, such calculations must also account for the expense of adopting and administering a reformed system: The administrative costs of imposing a perfectly allocated system may, in reality, be prohibitive.

Opponents of reform may argue that any tampering with consumer sovereignty would result in less allocative efficiency: Reforms which eliminate coercive remedies or supply services such as screening or therapy should not be imposed (so the argument might run) because if debtors or creditors wanted such reform they would purchase it. But if prospective debtors wish to purchase cheaper credit along with the chance of default and coercive creditor tactics, they should be allowed to do so. The opponents of reform may ask: Why run the high risk of misallocation by imposing reform when we already know what creditors and debtors want because we see them bargain for it in the marketplace?

But such arguments may fail to see the serious imperfections in the credit market which prevent the freely bargained supply of credit from being allocatively efficient. Such imperfections may lead to an oversupply or undersupply of credit regardless of the bargain between creditors and debtors. At times the effects may cancel each other out, but such a fortuitous result would be purely accidental.

16. Even this model of perfect allocation has built in biases representing value judg. ments about the desirability of allocative efficiency. See, c.g., R. KuevNe, MIıcro-EcoNOMIC THEORY OF THE MARket MEChanisM 363 (1968).

17. One additional complication occurs to the extent that various benefits and costs do not occur at once but only in the future. They must thus be rediced to present value. Also, labelling the effects "benefits" or "costs" is basically arbitrary, both because differing value judgments will suggest different categorization and because it is frequently unknown whether the actual magnitude of some of the cffects will be positive or negative.

18. See p. 476 infra. 


\section{A. Possible Imperfections in the Current Credit Market}

\section{Imperfections Leading to Undersupply}

Several imperfections exist in the credit market which may result in too little credit being purchased. These include:

Concentration in the credit industry. Instead of a highly competitive credit market in which creditors bid against each other to attract debtors, the credit market exhibits a large number of monopolistic characteristics, ${ }^{10}$ at least at the local level. Typically, a small number of creditors serve low-income areas and many low-income buyers do not have the transportation or information necessary to shop intelligently. Depending on the degree of monopoly and elasticity of demand for credit, creditors may raise prices to maximize their own profits, causing debtors to purchase a smaller quantity of credit than they would if the price reflected its real cost. Reform aimed at this imperfection might include an increase in debtor information, subsidies to debtor mobility, price ceilings on credit sales, or the elimination of artificial barriers to competition arising from present licensing laws.

Unavailable debtor services. Another imperfection contributing to undersupply is the lack of certain services for debtors which, if supplied, would make credit far more attractive. If, for example, at the time of entering the credit transaction debtors could purchase an insurance policy entitling them to assistance in the event of default, and if such assistance reduced the cost of future anguish by a greater amount than it increased costs, rational debtors would purchase more credit. Of course, if the service caused creditor costs to increase by an amount equal to or greater than the debtor's net gain (perhaps because debtors who no longer feared future anguish would not feel as great an incentive to repay) the competitive price of credit would increase to wipe out any debtor gain, and there would be no overall increase in the amount of credit purchased.

The free market has probably not exploited such potential increases in allocative efficiency and supplied such debtor services due to debtor short-sightedness and a lack of creditor ability to exploit economies of scale. To encourage debtors to demand such reforms, they could be supplied with information about the likelihood of future hardship and

19. See Smith, Description of Nine-Company Consumer Finance Sample and of Adjustments in Data in The Consumer FinANCE INDUSTRY 163, 164 (J. Chapman, R. Shay cds. 1967). "[N]ine [consumer finance] companies held $\$ 3.1$ billion in consumer reccivables at the end of 1964 and accounted for 66 per cent of the loans held by all consumer finance companies and 50 per cent of the receivables of all personal finance companics." 
the advantages of the debtor service. Reform might also subsidize creditors until economies of scale were reached.

Unavailable creditor services. A third imperfection in the credit market occurs to the extent that creditors do not differentiate between highrisk and low-risk debtors. Misallocations result when low-risk debtors purchase too little credit because credit is offered at too high a price relative to the risk that they will default, and high-risk debtors are purchasing too much credit at too low a price. If better information were available, creditors could price discriminate between such debtors. Better discrimination would enable them to reduce uncollectible debts and costly collection practices and, in a competitive market, offer a greater quantity of credit at lower prices. The reason that such services are not now available may have to do with legal difficulties blocking creditor cooperation or problems in achieving economies of scale. To the extent that the cost of such services when fully developed would be less than the cost savings they produced, reform which subsidizes or develops such services should increase allocative efficiency.

Macro-economic benefits. A final imperfection causing an undersupply of credit occurs to the extent that credit produces benefits other than those accruing to the purchaser. If such external benefits of credit were included in the credit transaction, more credit would be purchased. For example, consumer credit may well promote economic growth by permitting the anticipation of purchases and shifting demand toward durable goods industries which have greater potential for expansion. ${ }^{20}$ Of course, consumers must repay their loans with in-

20. For a review of the literature concerning the relationship between consumer credit and long-term growth, see Jones, Theories of Consumer Instalment Credit in Relation to Economic Stability, in I UNIred States Bd. of Govervors of Tue Fed. Res. Sis., CoxSUMER INSTALMENT CREDIT pt. I, 235 (1957) [hereinafter cited as CoNsuaer INSTALueit CREDIT].

The ingenuity of a number of economists has been taxed in trying to cxplain how economic growth is encouraged by consumer credit. The most common explanations in. clude the following: 1) Consumer credit produces a faster growing demand than other. wise, which through multiplier and accelerator effects encourages greater business and consumer spending. 2) Consumer credit acts automatically to temper the fluctuations of the business cycle. The result is more stable and lasting growth, and less use of fiscal or monetary manipulation. 3) Consumer credit encourages durables purchases and so shifts consumer demand into a sector of the economy which is most prone to technological innovation. 4) Sales resistance is reduced causing greater consumer spending (and less saving). See Taylor, Instalment Credit and Aggregate Demand in I CoNsusen Isistalusest CREDIr pt. I, 164, 176-77 (1957). 5) Consumer credit provides a spending outlet for savings that would otherwise remain as stagnant bank reserves. 6) In relation to the business cycle, consumer credit encourages a speedy up-turn. Therefore the expanding part of the business cycle is of longer duration than otherwise. 7 ) Because of the way consumer credit affects consumer behavior, the bottoms of cyclical fluctuations arc not as low as they otherwise would be. 8) Because consumer credit permits consumers to buy major durables, it gives the work force greater incentives, hence increasing both reliability and productivity. See Miller, Consumer Gredit and Economic Growth, in 1 Cossusser INstal- 
terest, thereby reducing later expenditures by a proportionate amount. But insofar as credit adds to the normal growth in demand, capital accumulation and technical innovation occur earlier, resulting in a more advanced economy with higher productivity.

Economic stability may be another macro-economic benefit of credit. It is often assumed that credit spurs the economy at the beginning of an upswing by allowing consumers to anticipate spending power. It is said to moderate downturns by providing consumers with the means of maintaining prior levels of consumption, thereby dampening the cyclical plunge. ${ }^{21}$ Unfortunately, studies to date fail to substantiate the assertion that the consumer credit system has such a favorable impact on growth and stability. If credit is now undersupplied to high-risk, low-income debtors, there is little evidence that such an undersupply significantly affects overall demand..$^{22}$ Thus, these possible external benefits to the economy generated by credit would not seem significant enough to warrant the risks and costs of reform.

\section{Imperfections Leading to Oversupply}

Market imperfections causing excessive use of credit occur to the extent that credit use generates costs which are greater than its actual price. If such external costs could be brought to bear on the credit transaction, the price of credit would be higher and less would be purchased. The most important of these costs include:

ment Credit pt. II, 169, 200 (1957). 9) Consumer credit shifts overall demand to durables which means that consumers then own a greater proportion of capital goods than otherwise. See Abramovitz, Comment, 1 Consumer Instalment Credit pt. 11, 246 et seq. (1957). See also Bouveng, Consumer Credit, Some Long Term Economic Aspects, 68 Swevisil J. Econ. 234 (1966).

21. See J. Vostermans, in I Consumer Instalment Credit, supra note 20, pt. I at 15 (1957).

22. Cf. McCracken, J. Mao \& C. Fricke, Study of Consumer Preferences in 9 Consumek INSTALMENT CREDIT, supra note $20, \mathrm{pt}$. II at 72 (1957). Even if all credit now cxtended to persons with incomes of less than $\$ 5,000$ were curtailed, only $1.35 \%$ of the total dollar volume of consumer credit would be lost. If that entire decrease affected durable goods sales, only $1.81 \%$ of such sales would be eliminated-certainly an insignificant thrcat to the economy. Moreover, since low-income consumers often pay two or threc times the value of a good purchased on credit, an undersupply of credit will have but a slight impact on overall demand. Moreover, a great deal of low-income borrowing involves refinancing or second-hand purchases, both of which have only the remotest effect on demand. Finally capital freed by such an undersupply in credit volume is indoubtedly diverted into other sectors of the economy, thereby spurring growth in those new sectors.

These percentages are derived by combining the percentage of families with instalinent debt in income groups below $\$ 5,000$ and the percentage of total families in the United States which are in these income groups. The combined percentage is then multiplicd by the total number of families in the United States to get a figure representing the number of families in the United States in those income groups who have instalment debt. The figure is then multiplied by the median debt of the income groups to get the total dollar amount of credit outstanding for those earning below $\$ 5,000$. Credit outstanding for that income group is then divided by the total outstanding to get the percentage of total outstanding which represents loans to those earning below $\$ 5,000$. 
Public subsidization of the regulatory system. Society as a whole now finances the apparatus which regulates the credit market-the judges, administrators, legal service lawyers, enforcement officials, and clerical employees. The payment of such expenses is a clear subsidization of the credit market. ${ }^{23}$

Lost productivity. Another external cost to society consists of work time lost by debtors due to court appearances, meetings with creditors, and general psychological stress. ${ }^{24}$ Many debtors may be forced to take jobs not commensurate with their skills or hazardous to their health in order to cope with economic crisis. Others may lose their jobs and spend days or months finding another. ${ }^{25}$ Entire families may be affected: For example, the debtors' children may terminate their education in order to take low-skill jobs, thereby missing vocational opportunities and reducing the economy's productivity.

Loss of respect for government. Those who are subjected to coercive collection tactics employed by the present system, as some empirical studies show, ${ }^{26}$ may emerge from the process with much less respect for the courts and legal system. Such attitudes may make it more difficult to maintain an ordered society, particularly when all the entire debtor's family is affected.

Hardship for debtor and family. In addition to these costs to society in general, substantial burdens accrue to the debtors themselves-burdens which are not reflected in the price of credit. The debtor must endure the hardship of repaying debts when, as a result, his personal standard of living is reduced and his financial flexibility limited. The

23. That most creditor actions filed go to default judgment strongly stuggests that creditor use of regulatory apparatus is much greater than debtor use. Sec D. Cirtorrr, supra note 7, at 11-66; U.C.L.A. Project, supra note 3, at 891 .

See generally INStrtute of Judicial Adp., State \& Local Financing of the Counts (tentative ed. 1969); U.S. ADvisory CoMmission ON INTERgoverniseital Relatioss, State. Local Relations in the Criminal Justice SyStear (1971).

24. See D. Caplovitz, supra note 7 , at 14-7 to $14-8$.

25. See, e.g., D. Caplovitz, supra note 7, 14-6 to 14-13; H. JAcon, supra note 6, at 104 . Caplovitz found that eight per cent of his sample of debtors who worked in states with wage garnishment lost their jobs. When the focus was narrowed to those debtors whose wages were garnished, nineteen per cent lost their jobs. Seven per cent of Jacob's sample of garnished debtors reported being fired, while seventeen per cent realled being warned that additional garnishments might jeopardize their jobs.

26. See H. JACOB, supra note 6, at 117-24. In Jacob's study, forty per cent of the garnishees studied were either ambivalent or reported that the system treated them unfairly. Eleven per cent of the bankrupts had the same reaction. Id. at 117. Of course, insofar as the debtor's disaffection with the judicial process results from more intimate knowledge rather than unfair treatment, it would appear impossible to design reform which would reduce disaffection unless it also reduced debtor contact with the system. It has been hypothesized that consumer credit difficulty was a causal factor in the attitudes which led to the riots of 1966 and 1967. See U.S. National ADvisoni Conmission on Civil Disorders, RePort $139-40$ (1968); Note, Consumer Legislation and the Poor, 76 YALE L.J. 745,746 (1967). Yet there is no clear evidence that a real causal connection existed. 
debtor may suffer the frustration of being unable to obtain a remedy for faulty goods because the credit contract does not permit him to withhold the balance of the purchase price from the creditor-assignee of the seller. ${ }^{27} \mathrm{He}$ may also suffer from psychological pressure inherent in devices such as repossession, deficiency judgments, garnishment, and other execution processes. Simultaneously, he may face the social censure and personal guilt associated with the failure to meet his obligations. A number of recent studies substantiate the magnitude of anguish, shame, and suffering associated with default and the present coercive remedies. Nearly forty-five per cent of Caplovitz's study' reported physical ailments assertedly related to the pressures of default. ${ }^{28}$ Other defaulters have reported increased marital difficulty, reduced expenditures on food and other living expenses, and substantial worry over loss of employment. ${ }^{29}$ Many of these costs may undergo a kind of multiplier effect as the debtor's suffering affects his entire family. ${ }^{\mathbf{B 0}}$

The current system cannot allocate credit efficiently if debtors who enter the credit transaction fail to appreciate the probability of default occurring and the consequences following for themselves and their families. If the debtor underestimates either the probability of default or the amount of hardship resulting therefrom he will demand more credit than his informed preferences would dictate. If most debtors underestimate these risks, the demand for credit will be inflated.

\section{Reform Techniques for Reducing Oversupply}

Reform could aim at eliminating such external costs, e.g., by pro. hibiting the coercive creditor practices which cause them, or at bring-

27. Of course it should be noted that inroads have been made into the protected status of creditor-assignees in the consumer credit field. See, e.g., Fairfield Credit Corp. v. Donnelly, 158 Conn. 543, 264 A.2d 547 (1969) (waiver of defense clause in retail sales installment contract held void as against public policy); Norman v. World Wide Distribu. tor's Inc., 202 Pa. Super. 53, 195 A.2d 115 (1963) (holder in due course protection unavallable to assignee put on inquiry as to assignor's fraudulent selling practices). Recently it has been recognized that related problems exist in the credit card and "loan related to sale" field. See generally Comment, Waiver of Defense Clauses in Three Party Consumer Credit Card Transactions, 11 B.C. IND. \& CoM. L. REv. 991 (1970). For a proposed pro. vision aimed at the "loan related to sale" problem, see National Consumek Acr \$2.407 (First Final Draft, 1970).

28. See D. Caplovitz, supra note 7, at 14-13, 14-20.

29. See H. JACOB, supra note 6, at 114. These social costs may be quite high when the population is viewed as a whole. Professor Spanogle suggests that between 400,000 to $\mathbf{7 0 0 , 0 0 0}$ families per year have debt trouble. See Spanogle, The Consumer in Trouble in the United States, in Aspects of Comparative Commercial Law 269 (J. Ziegcl \& W. Foster eds. 1969). Caplovitz suggests (by extrapolating from four American cities) that threc million defaulters are sued yearly. See D. CAplovirz, supra note 12, at 14.8. Neither Spanogle nor Caplovitz indicates clearly how he derived his totals.

30. See D. CAPlovitz, supra note 7, at 14-20 to 14-22. Contra, H. Jacon, supra notc 6, at 105. See also Herrmann, Families in Bankruptcy-A Survey of Recent Studies, $28 \mathrm{~J}$. Marriage \& Family 324 (1966); Matsen, Profile of the Problem User of Credit-The Bank: rupt, in National Workshop on Consumer Credit in Family Financlal Management, Consumer Credit in Family Financial Management 73 (1967). 
ing the costs to bear in the credit transaction. Prohibition risks eliminating benefits that may, in some cases, exceed the costs which are eliminated. Further, some of these costs are so difficult to quantify or so remote that an error in estimating them may wipe out any prospective gain. Those costs for which the risk of such error is substantial should therefore not be internalized. It would seem that reform could most easily aim at internalizing the costs falling upon the debtor and his family.

Reform could respond to the external costs falling upon the debtor and his family in three distinct ways: By so improving debtor foresight of the risks and consequences of default that these consequences would no longer be "external" to the credit bargain; by prohibiting the causes of the costs; and by internalizing the costs through a kind of corrective tax levy.

\section{a. Debtor education}

Debtors might be forced to recognize the probability of default occurring and the consequences following default through a program of education and counseling. If the debtor could be compelled to feel the depth of hardship associated with default, his demand for credit would reflect more accurately his true preferences. His demand for credit would be further enlightened if he could estimate more accurately his particular level of risk. If debtor demand for credit then fell, the competitive creditor would have a choice: either maintain coercive remedies and sell credit at the new lower price, or eliminate coercion and sell at a higher price reflecting the increased creditor costs resulting from such elimination. If the cost to the creditor of eliminating remedies is higher than the cost to the informed debtor of having them employed, the creditor will be content to sell credit with coercion at the lower price; if not, the creditor will eliminate the devices. The creditor's choice would be, in any case, an allocatively efficient one.

Of course, an education program sufficiently graphic to alter consumer behavior probably would be extraordinarily difficult to construct. Counseling in this area has rarely proven effective because of the strong consumer biases in favor of immediate gratification and an unwillingness to take full account of future hardship and risk. ${ }^{3 x}$ For

31. The whole thrust of manipulative and want-stimulating advertising is toward immediate gratification. While the advertising establishment has done an excellent job of proclaiming the value of present consumption, it has said very little about the value of later consumption and present saving. Even if information about the benefits of saving as against the costs of credit use could be provided, information about the actual emotional state (level of satisfaction) that will occur in the future cannot be provided.

The inability of consumers to accurately balance future costs against present and 
such an education program to be successful, it would have to affect the deepest of character traits; even if that were possible, the costs of doing so would probably exceed any concomitant gains in allocative efficiency.

\section{b. Prohibition of certain creditor remedies}

If coercive creditor techniques were simply abolished there would obviously be no need to internalize their harmful effects. But any such elimination of creditor remedies would fail to produce allocative efficiency if creditor costs were thereby increased more than the harm to debtors was decreased. If this occurred, the competitive price of credit would rise above the price sufficient to internalize the hardships of coercive remedies. Such a situation should be unlikely, however, as the value of coercive remedies to creditors is generally low while the costs to debtors are high. Moreover, creditors deprived of coercive remedies would have more incentive to improve their own information systems, thus increasing their capacity to assess the riskiness of individual debtors and reducing another market imperfection..$^{32}$ They would also have more incentive to control the sales practices and quality of items bought with credit. ${ }^{33}$ Instead of insisting on payment from debtors who indicate strong dissatisfaction with purchased items, creditors would be more likely to throw the credit contract back to the seller under a repurchase agreement. ${ }^{34}$

It should be noted, however, that abolition of creditor remedies may have costly side effects. The concomitant price increase might trigger, for example, an underworld loan shark market which employed genuinely abusive, self-help remedies. And abolition may not ameliorate entirely the anguish, shame and loss of self-respect which commonly result from default. In order to eliminate such guilt, reform might have to alter the definition of default, e.g., by making liable only those whose failure to pay resulted from negligence or bad faith. ${ }^{3 \mathrm{~b}}$

future benefits has been insisted on by some writers and challenged by others. Compare Jukerji, Two Papers on Time in Economics, 7 ARTha VIJNAna 296 (1965) and Danicliall, The Theory of Consumers' Credit, 19 AM. ECon. REv. 393, 397 (1929), with W. Mors, CoN* sumers Credit Theories 21, 23 (1944). Professor Mors surveys the disputants prior to 1944. See id. at 28.

32. See p. 463 supra.

33. See Littlefield, Preserving Consumer Defenses: Plugging the Loophole in the New UCCC, 44 N.Y.U. L. REv. 272, 280-86 (1969).

34. See Comment, $A$ Case Study of the Impact of Consumer Legislation: The Elimi. nation of Negotiability and the Cooling-Off Period, 78 YALE L.J. 618, 640 (1969). The Yale study bases this statement on a survey of eleven banks engaged in financing homc solicitation sales after 1967. For strong criticism of the methodology of the Yale study, see Shuchman, Empirical Studies in Commercial Law, 23 J. LEG. Ev. 181, 183.84 (1971).

35. The proof problems caused by providing debtors with the defense that they have not negligently or wilfully caused the default would be substantial. When, for example, 
One might also consider programs designed to aid the debtor and his family-to teach them to marshal their assets and bargain with their creditors, while at the same time adjusting them to the idea that they were overcommitted. ${ }^{36}$ Such a program, perhaps financed by the creditors much as is their fire insurance, could combine, as in Great Britain, ${ }^{37}$ legal and social aid in one agency. Creditor financing would of course have allocative effects of its own.

\section{c. Internalization through specific levies}

Government might intervene to internalize the costs of creditor remedies by imposing a direct charge, equal to the estimated external costs, on their use. The charge might be imposed on any credit contract which provided for coercive remedies, or it might be imposed upon the actual use of such remedies. It would promote allocative efficiency to the extent that it compelled creditors to avoid the use of coercive remedies whenever the social cost of using them exceeded the benefits. Thus, the competitive price of credit would reflect either the social cost of the coercive remedy or the cost to the creditor of foresaking it, whichever was lower.

Two objections can be raised against such a proposal. It might be contended first that the external costs would be impossible for the government to quantify and translate into selective charges. In response, it may be argued that the calculation would be possible within a certain acceptable margin of error.

Secondly, one might object that it seems unjust and irrational for debtors to end up paying for charges which reflect the likely hardships they will endure from coercive remedies. That is, while the user charge may produce allocative efficiency, its distributive impact would be regressive. This objection might be met if the proceeds of the charges were used to subsidize debtors who incurred the hardships of default. While such subsidies might have a detrimental impact on allocative efficiency to the extent debtors relied on them, the risk seems rather small in light of the distributive equities involved.

has a debtor been negligent? Either the matter could be left to the courts for definition or clear indicia of non-negligent conduct would be written into the reform. Thus a defense could be that the debtor had lost his source of income through lay-off, firing. or illness. See Kripke, Credit Oriented, supra note 2, at 477 for a less drastic proposal.

36. Debt counseling agencies best approach this model. See M. Hald. Sumarar REport on Family Credit Counselling-AN Emercing Communin Service (1968). Since a number of these agencies are funded in part by local creditors, however, they tend not to indicate to the debtor that he is simply unable to repay his debts.

37. See Lythe, Looking Around?, 16 CASE CoNFERENice 39 (1969). 


\section{B. Will Reform Increase Administrative Costs?}

The impact of reform on governmental expenditures would vary tremendously, with the reform package chosen. A package that reduced the risk of underestimating or overestimating the externalities of the present system might entail huge administrative expenditures, while a package that more or less ignored the risk of misallocations might actually involve less administrative expense than the present system. For example, attempts to achieve the optimal allocation of credit resources through economic analysis and to limit by government regulation credit resources to that prescribed allocation, might be less costly than an attempt to achieve that allocation by rebuilding the market. Although the costs of such analysis and direct regulation would undoubtedly be large, the costs of rebuilding the market could be even larger. Yet, that market, once rebuilt, might be capable of automatically producing a better allocation of resources than one imposed by the government.

If there is a trade-off between risk of misallocation and administrative expense, one goal of reform should be to find the best mix between the two. It might be, for example, that if defaulting debtors were liable only for negligent default, creditors would be less likely to use the court system, and judicial expenses would thereby decrease. For the trade-off to work, however, this decrease would have to offset the additional expense of the new means of handling non-negligent defaults. ${ }^{38}$

Of course, even if the costs of administering reform were substantial, those costs might well produce further savings elsewhere in the credit system. For example, if the government were to provide the service of "skip-tracing" interstate debtors, its administrative cost might be less than the cost of an analogous service carried on by creditors.

In light of these uncertainties and risks, reform in consumer credit should be instituted wherever possible as an experiment to be adjusted periodically, rather than a permanent panacea. Experimenting through the legislative process may, of course, be difficult, as a government benefit once conferred is often difficult politically to retract. But the prospect of achieving substantial credit reform without major administrative expense appears to justify some experimentation. Reforms involving even substantial regulatory cost might also be attempted, if the

38. Of course, any savings would depend upon how debtors and creditors reacted to the reforms. While limitations upon creditor remedies might reduce creditor reliance upon the court, they might at the same time encourage debtors to defend more often. 
potential gains in allocative efficiency appeared great enough to support the risk. Still, there are likely to be some technical difficulties in measuring external costs, and political problems in convincing legislatures to terminate unsuccessful reform experiments.

\section{Consumer Credit Reform and Wealth Distribution}

Another basis for evaluating consumer credit reform would be its effect on the distribution of wealth. Such a concern is obviously relevant to credit reform; indeed the ostensible motive behind many reform proposals is to reduce the suffering and injustice visited on those who cannot pay their exorbitant debts. Moreover, there are few who would vent their disapproval of the present system by denying highrisk borrowers the opportunity to borrow. Thus, the question inevitably arises: If reform ends the credit of the poor, high-risk debtor, is he really helped?

The argument that consumer credit reform will deny low-income consumers credit and thereby worsen their plight begins with the assertion, discussed above, ${ }^{39}$ that reform will increase creditor costs, producing a credit price increase or volume reduction. But even if such events occur, it may not follow that this loss of credit would markedly affect the distribution of wealth.

Such a loss will not affect individual purchasing power. ${ }^{40}$ Although credit does enable the low-income consumer to purchase goods and services without recourse to savings or current income, thereby creating a semblance of increased purchasing power in the short run, his net purchasing power in the long run will be less than that of a consumer who does not borrow: The credit consumer must eventually pay for his credit, and these interest payments will reduce his subsequent purchasing power.

Short term increases in purchasing power may, however, produce advantages which the low-income consumer would otherwise be denied. First, the credit purchase of certain durable goods may provide the consumer with long-term economies (for example, the use of a

39. See p. 462 supra.

40. See, e.g., Ziegel \& Olley, Foreword, to Consusar Credrt IN Cunadi iii U. Ziegel \& R. Olley eds. 1966) [hereinafter cited as Canada]. Professor Kripke urges that consumer credit should not be restricted because to do so would deny consumer goods to "law-abiding members of the dispossessed, who get the possessions they want from credit purchases." Kripke, Credit Oriented, supra note 2, at 479. 
private washing machine instead of public laundry). ${ }^{41}$ Second, credit purchase before sufficient savings have been accumulated could provide the consumer with a hedge against inflation which might otherwise sap the value of such savings. ${ }^{42}$ Third, credit may provide the consumer lacking discipline to save for durables with an attractive forcedsavings device. ${ }^{43}$ Fourth, it may give consumers the psychic benefit of being able to consume above their normal income level. ${ }^{44}$ Fifth, it may prove a means for withstanding temporary economic adversities such as job loss or illness. ${ }^{4 \overline{5}}$ Finally, and perhaps most importantly, credit purchases made before the accumulation of savings often allow younger people to enjoy goods they will ultimately be able to afford, by allowing them to redistribute their lifetime earnings to best fit their needs. ${ }^{40}$

Simultaneously, a denial of credit may cause specific hardships. The very process of being refused credit may produce embarrassment and humiliation. The stigma of having been judged unworthy of credit is similar to the defaulter's sense of guilt, ${ }^{47}$ though the poor credit risk will probably cease seeking credit and accept his no-credit status. However, such acceptance may take the form of turning to criminal sources for credit. ${ }^{48}$ As noted above, in such a situation both the real and hid-

41. See Neufield, The Economic Significance of Consumer Credit in CANADA, supra note 40, at 5, 9. Professor Neufield here relies on a study which found that substantial savings resulted from the use of a television over other outside entertainment. Yet if the consumer is unwise, he may actually spend more for the good than for the particular service. See also Mors, Commentary, in CANADA, supra note 40, at 19, 22 n.10. It would seem likely that consumer credit is used to purchase luxuries-that is, a good which represents a stream of services more expensive than what the consumer already has.

42. The significance of this benefit should not be overestimated. As long as in. flation remains at a fairly predictable rate, both credit prices and interest paid by savings institutions will reflect that rate. Thus this benefit will be realized only in extreme, run. away inflation, which this country has not experienced in this century.

43. Economic studies do not suggest that consumer credit results in increased liquidity. Advertisements from finance companies, however, often suggest that consumer credit use results in "savings." Professor Neufield notes that the increased disposable income may actually be saved, but is careful to insist that there is no certainty that this will occur. Since Neufield also finds that consumer saving is relatively unaffected by the lcvel of consumer credit use, it may be equally likely that the increase in disposable incomc will instead be spent on consumption. See Neufield, supra note 41 .

44. Of course, this advantage is essentially short term. Where families try to use it for the long term, disaster results. Moreover, its value would seem less clear as welfare pro. grams improve. See also Fortin, The Social Meaning and Implications of Consumer Credit, in CANADA, supra note 40, at 30. Professor Fortin describes a class of borrowers who chronically use credit to increase what they consider to be an inadequate income. $\mathbf{A t}$ a certain point, repayments can no longer be refinanced, and massive default occurs.

45. See, e.g., Neufield, supra note 41 , at 10 .

46. See Thurow, The Optimum Lifetime Distribution of Consumption Expenditur's, 59 Am. Econ. Rev. 324 (1969). See also W. Mors, Consumer-Credit Theokies 21 (1941).

47. See p. 472 supra.

48. Professor Kripke (and others) suggest that one effect of reform may be to drive debtors to borrowing from loan sharks. See Kripke, Gesture, supra notc 2, at 34. The argu. ment assumes that 1) the effect of reform would be to increase creditor costs and 2) that usury ceilings would prevent the creditor from passing on those costs to debtors in the form of increased prices. Thus, reputable creditors would leave the low-income market 
den external costs of credit may increase to rather gruesome proportions. Of course, the risk and high prices associated with such borrowing should discourage most debtors from pursuing this alternative under normal conditions. And even if debtors did desire such loans, a simple way of urging them back into the legitimate market would be to eliminate usury ceilings and allow prices to increase dramatically with risk. ${ }^{49}$

In sum, credit may provide flexibility, ease, and economy-advantages which bear a direct relationship to the willingness of debtors to pay the price of credit. Thus, denying credit to high-risk debtors may cause them some frustration, although they may gain both by not paying interest charges and by avoiding the hardships associated with default. These latter gains may, in fact, outweigh the disadvantages from the absence of credit. Indeed, reform may be viewed as providing a benefit to everyone who uses credit by reducing the risk of serious hardship associated with default. In this way, price increases or volume reductions caused by reform may be seen as "payments" for compulsory insurance against misfortune.

How well these increases or reductions match the risk depends, of course, on how broadly the risk category is defined. If, in order to guard against losses in a reformed system, creditors respond by charging all their customers the same higher price or reducing the amount of credit available to all regardless of risk, the low-risk (and more wealthy) borrowers will be subsidizing the insurance of the high-risk (and poorer) ones. There will thus be a wealth transfer from rich to poor. But if, on the other hand, creditors discriminate according to risk, there will be less of this transfer effect. Of course, the actual distribution is likely to be far more complicated. If the credit market is segmented between low-risk, wealthy debtors borrowing from banks, and higher-risk, poor debtors borrowing from loan companies, the banks may not respond to reforms at all, while the loan companies would probably increase their prices substantially. If this happened, wealth would be redistributed to some degree from low-income borrowers who repaid their debts to those who did not. Meanwhile, the highest risk debtors would probably be denied loans altogether. In any

and the low-income debtor would be forced to turn to illegal lenders. Here, there is little assurance that illegal lenders carefully relate their prices to their costs, and their collection tactics may include maiming and murder. 113 CoNG. REc. 24460, 24461 (1967) (Study of Organized Crime and the Urban Poor, remarks by Representative McDade).

49. The simple answer to the problem of loan sharks is that reform should include provisions sufficient to keep reputable lenders in the low-income market. Either usury rates should be increased, subsidies provided, or other reforms designed so that creditor costs would not seriously increase. 
case, regardless of how segmented the credit market, poor debtors would not necessarily find themselves worse off; some, in fact, might be better off.

To the extent that reform did not increase creditor expenses, it would have very little wealth transfer impact on creditors. Even if it does raise operating costs, creditors might pass a part of the costs on to debtors unless, as suggested above, ${ }^{50}$ demand for credit is highly elastic and at the same time creditors already enjoy monopoly profits. Yet, even under these conditions, little wealth transfer is likely to result because creditors would, in the long term, withdraw their investments from credit markets and reinvest in other sectors of the economy. Thus the only possible transfer of wealth away from the creditor would occur if the profit margin in the credit industry were substantially higher than in other investment opportunities. Yet studies indicate the contrary. ${ }^{51}$

There is thus no certainty whatever that the wealth distribution impact of consumer credit reform would be regressive. If a given consumer credit reform did not increase creditor expenses, little or no redistribution would occur, though debtors as a group might be better off than they were before reform. If, instead, reform did increase creditor costs and the demand for credit were relatively inelastic, creditors would be likely to pass the increased costs along to the debtors; a wealth transfer might then occur from lower-risk debtors to higher-risk debtors who pay the same price for credit. If reform increased creditor costs and the demand for credit were relatively elastic, creditors might lose some wealth in reducing the volume of credit offered and converting their investments to other sectors of the economy; debtors who under these circumstances refrained from paying the higher price of credit might also lose certain advantages associated with credit, but would gain by avoiding the risk of default.

\section{Value Choices}

An evaluation of various consumer credit reforms can go only so far. There will be some critics who insist that any benefits from reform

50. See p. 466 supra.

51. The major study of the rate of return for consumer finance companles finds at average return of $12.2 \%$ net profits to equity funds. See Smith, Recent Trends in th Financial Position of Nine Major Consumer Finance Companies in TuE Consuntes 1 NANCE INDUSTrY 49 (J. Chapman \& R. Shay eds. 1967). Though this is somewhat great than other rates of return, the lower risk and greater ease of administration for busine loans may make the investment opportunities in the general business market mo attractive to the average lender. 
are not as significant as the moral effrontery of allowing defaulting debtors to avoid their just deserts. Other critics will claim that debtors should be free to choose the high-risk of future suffering if that is what they want. Still others may argue that if we are interested in increasing allocative efficiency or redistributing wealth, there are far easier and more efficient ways of doing so than by becoming embroiled in the consumer credit market.

To admit the validity of such criticisms is merely to acknowledge that value choices underlie all policy decisions, and that argument must, after a certain point, give way to the most basic value differences. Yet it should be noted that some reforms may challenge basic values less than others. Reforms which are not likely to increase creditor costs present few difficulties for critics who are concerned about freedom of choice or the means of redistributing wealth, since such reform may be relatively inexpensive. The abolition of holder-in-due-course devices, restriction of wage garnishment, and the removal of the "blanket" clauses which give the creditor an interest in virtually all the debtor's household goods appear to fall in this class.

Other proposals which seem likely to increase creditor costs and thus affect the price or volume of credit include the restriction of coercive tactics available to creditors after default, abolition of deficiency and default judgments, and article nine repossession. When high-risk debtors are forced to forego credit because of such reforms, critics worried about freedom of choice are likely to argue that high-risk debtors should at least have the option of purchasing credit at a lower price and at a higher risk of misfortune..$^{52}$ These critics may well reject reformers' repeated warnings that consumers have a shortsighted bias in favor of immediate gratification, lack bargaining strength, and are likely to fall victim to advertising. When the cost of reform is not internalized within the credit transaction but subsidized by the government instead, critics concerned with efficiency are likely to claim that there are cheaper ways of maximizing social welfare and redistributing wealth; and critics concerned with redistribution are likely to argue that general taxpayers should not pay for the faults of a few culpable debtors. These critics are in effect refusing to accept debtor difficulty as a general misfortune falling upon various income groups at various

52. See also Consumer Finance Companies in CoNsuarer Instalarest Credr, supta note 20, pt. III at $98-100$. 
times, similar to job loss or temporary illness as an appropriate concern of government. . $^{53}$

Thus, we can only indicate the appropriate questions that need to be asked, highlighting those areas where more empirical work is needed. Proposals for consumer credit reform abound. What is most needed now is a willingness to evaluate them rationally, confining disagreement to ultimate differences in values.

53. Caplovitz found that a very high proportion of his sample reported interruption in income as the cause of default. Nearly half the sample individuals gave income loss as one of several reasons for default and $43 \%$ of those sampled gave it as the first rea. son. See D. Caplovitz, supra note 7 , at $5.1,5.2$. The role of illness in default is unclear. H. ЈАСОВ, supra note 11 , at 52 , finds that $90 \%$ of his sample reported doctors' bills in their unpaid debts. Other studies reported large medical bills. See also E. REEv. P'E. SONAL BANKRUPTCIES IN OREGON 95 (1967) $(85 \%$ of bankrupts have medical bills, and they account for $10 \%$ of total debt less real estate). Caplovitz finds that only $36 \%$ of his sampled debtors indicated that overextension was an important cause of default and therefore it was less important than income loss. 